\title{
Fresh Ready-Mixed Concrete Waste in Construction Projects: A Planning Approach
}

\author{
Aynur Kazaz \\ Department of Civil \\ Engineering, Faculty of \\ Engineering, Akdeniz \\ University, Turkey, \\ akazaz@akdeniz.edu.tr
}

Volkan Arslan

Department of Civil

Engineering, Faculty of

Engineering, Bulent Ecevit

University, Turkey,

volkan.arslan@beun.edu.tr

\author{
Serdar Ulubeyli \\ Department of Civil \\ Engineering, Faculty of \\ Engineering, Bulent Ecevit \\ University, Turkey, \\ ulubeyli@beun.edu.tr
}

Murat Atici

Department of Civil

Engineering, Faculty of

Engineering, Akdeniz

University, Turkey,

aticimurat@yandex.com
Bayram Er

Department of Civil

Engineering, Faculty of

Engineering, Akdeniz

University, Turkey,

bayramer@akdeniz.edu.tr

Ahmet Arslan

Department of Civil

Engineering, Faculty of

Engineering, Akdeniz

University, Turkey,

arslnahmto7@hotmail.com

\section{Keywords}

Concrete waste;

Construction projects; Fresh concrete; Project planning;

Ready-mixed concrete
IN THE CURRENT STUDY, HOW PLANNING AND TRUCK-MIXER BASED WASTE AMOUNTS PER $1 \mathrm{M}^{3}$ FRESH READY-MIXED CONCRETE (RMC) CAN BE DETERMINED WAS PRESENTED. Toward this aim, the formation process of the fresh RMC waste in construction projects was first introduced in a detailed manner, together with an in-depth literature review in this specific domain of the construction engineering and management. Then, the measurement procedure of the waste amount or coefficient of the fresh RMC was revealed and discussed as a practical and creative planning knowledge. Hence, a useful and realistic waste management perspective about the cost and potential environmental savings of the RMC waste was drawn. 


\section{Introduction}

Construction wastes not only affect the economy of a country, but also consume natural resources and pollute the environment for a very long term. According to Garvin (2004), 40-50\% of the energy produced in the world and $16 \%$ of available water resources are consumed to produce construction materials defined as waste. $\mathrm{CO}_{2}$ that appears in the production process of such materials makes up $50 \%$ of the total $\mathrm{CO}_{2}$ emission in construction. Given the transportation of these material wastes, this share of $50 \%$ likely reaches up to $75 \%$. In this environmental pollution and resource consumption, it should be noted that the cement manufacture plays an important role. In addition, construction wastes occupy large areas by volume. They have a share of approximately $20-40 \%$ of the total area occupied by wastes in the US, Canada, Hong Kong, Australia, Japan, and European Union countries (Stokoe, Kwong \& Lau, 1999; Kibert, 2000; Poon, 2007). This share can likely increase further if wastes are measured in weight (Mulheron, 1988; Hendriks \& Pietersen, 2000).

Today, the construction industry tries to deal with enormous amounts of wastes as they are very damaging to the environment. However, it is very hard to assert that the construction industry has generally constituted and improved its waste-based business culture so far. In order to reveal the current position of the construction industry as a whole in terms of types and amounts of construction wastes, it is inevitable that various types of estimates and plans on sub-sectors of the construction industry should be carried out.

In this context, how planning and truck-mixer based waste amounts per $1 \mathrm{~m}^{3}$ fresh ready-mixed concrete (RMC) can be determined was presented in the current paper as a part of an on-going research project. This is because, in a reinforced-concrete building project, concrete can have a big share of about $10 \%$ of the total project budget (Kazaz, Ulubeyli \& Turker, 2004). Of course, these amounts can be single numbers or interval-based values. This decision can be based on a statistical analysis of the real world data. Thus, while preparing their proposals, construction contractors in general and quantity surveyors and cost managers in particular can better estimate the amount and cost of RMC by means of these numerical values, and can take some preventive measures to decrease these wastes. In other words, construction contractors will neither order excessive RMC nor bear the related additional cost. Project owners can make realistic estimates on the total project cost by employing these unit waste amounts in the calculation of the planned budget. With an accurate estimation of the amount of the RMC waste, RMC firms can save both RMC and its raw materials (i.e., aggregate, cement, and water) by related preventive and recycling efforts. In addition, by revealing the causes of the formation of the fresh RMC waste, responsibilities of construction contractors and RMC producers can be determined to prevent and minimize this kind of wastes. From another perspective, according to TRMCA (2014), RMC of 102 million cubic meters was produced in Turkey in 2013. With this production amount, Turkey is in the first rank in Europe and in the third rank in the world after China and the US. Considering this huge consumption volume of RMC, it is evident that, both in Turkey and in other countries that consume high amounts of RMC, the determination of the accurate amount of the RMC waste has a vital aspect for customers, producers, and society in terms of the cost-effective business, sustainable natural resources, energysaving processes, and the environmental pollution. Moreover, this amount can be used in the solution of conflicts between RMC producers and consumers about the amount of RMC delivered or about the loss of RMC.

\section{Fresh RMC waste}

In construction projects, amounts of materials used both in the cost estimating process by owners or their consultants and in the cost planning process by main contractors are determined through detailed quantity surveying studies on project drawings. However, given current on-site practices, it is nearly inevitable that there are almost always some natural differences between planned values calculated in quantity surveying studies and real material amounts used in construction job-sites because of some reasons such as poor workmanship and losses during the transportation and placing activities. In order to take into account these differences, planning engineers and technical personnel in construction projects assign some practical specific coefficients or percentages without making any measurement, but by being based totally on their own experience. It means that the nominal waste for each material is waste allowances typically used by construction companies in their quantity and cost estimates. Basically, they multiply these specific values by amounts of related materials and finally find out the last quantities that will be used in construction projects (Ritz, 1994; Lewis, 2001; Kerzner, 2009). However, these last material quantities become different from those in practice owing to the fact that these coefficients cannot be successfully estimated and that some unexpected wastes are thus automatically created. In fact, this is because material wastes cannot be completely avoided and prevented due to different production methods and products in construction sites and unqualified quantity surveyors and estimators (Winkler, 2010).

Especially in the last decade, many research studies have focused on the construction waste quantification issue. These specifically include waste generation activities both in the construction of new buildings 
and in civil and infrastructural works such as highways, bridges, airports, and dams. When looking at them at the country level, it is observed that different countries around the world have been investigated in this regard. Among them, there are (i) European countries such as Netherlands (Bossink \& Brouwers, 1996), Greece (Banias, Achillas, Vlachokostas, Moussiopoulos \& Papaioannou, 2011), Norway (Bergsdal, Bohne \& Brattebo, 2007), Ireland (Kelly \& Hanahoe, 2008), Cyprus (Kourmpanis, Papadopoulos, Moustakas, Kourmoussis, Stylianou \& Loizidou, 2008), Spain (SolisGuzman, Marrero, Montes-Delgado \& Ramirez-De-Arellano, 2009; Lage, Abella, Herrero \& Ordonez, 2010; Llatas, 2011; de Guzman Baez, Villoria Saez, del Rio Merino \& Garcia Navarro, 2012; Saez, Merino \& Porras-Amores, 2012; Mercader-Moyano \& Ramírezde-Arellano-Agudo, 2013), Portugal (Coelho \& de Brito, 2011a,b; De Melo, Goncalves \& Martins, 2011; Malia, de Brito, Pinheiro \& Bravo, 2013), and Germany (Hoglmeier, Weber-Blaschke
\& Richter, 2013), (ii) Asian countries such as Hong Kong (Tam, 2008; Jaillon, Poon \& Chiang, 2009; Cheng \& Ma, 2013; Li \& Zhang, 2013), Taiwan (Hsiao, Huang, Yu \& Wernick, 2002), Malaysia (Begum, Siwar, Pereira \& Jaafar, 2006; Lau, Whyte \& Law, 2008; Masudi, Hassan, Mahmood, Mokhtar \& Sulaiman, 2011; Mokhtar, Mahmood, Hassan, Masudi \& Sulaiman, 2011; Che Hasan, Yusof, Mohd Ridzuan, Atan, Noordin \& Abdul Ghani, 2013; Nagapan, Rahman, Asmi \& Adnan, 2013), China (Li, Ding, Mi \& Wang, 2013), Japan (Hashimoto, Tanikawa \& Moriguchi, 2009), and Thailand (Kofoworola \& Gheewala, 2009), (iii) American countries such as the US (Cochran \& Townsend, 2010), Canada (Wimalasena, Ruwanpura \& Hettiaratchi, 2010), and Brazil (Formoso, Soibelman, De Cesare \& Isatto, 2002), (iv) Middle Eastern countries such as Kuwait (Kartam, Al-Mutairi, Al-Ghusain \& Al-Humoud, 2004), Palestine (Al-Sari, Al-Khatib, Avraamides \& Fatta-Kassinos, 2012), Israel (Katz \& Baum, 2011), and Lebanon (Tamraz, Srour \& Chehab, 2011), and lastly (v) Australia (McDonald \& Smithers, 1998).

The concrete waste is among the most important types of material wastes in construction projects. They accounts of approximately $50-55 \%$ of the total construction waste generation by weight (Mulheron, 1988; Hendriks \& Pietersen, 2000; Tam \& Tam, 2007). Numerous academic researchers in theory and many concrete manufacturers in practice attach significant importance to recycling and reusing issues of the concrete waste. This kind of studies in the related literature have usually been directed to the use of the crushed concrete waste either as a road-base fill material or in place of the virgin or artificial aggregate for the new concrete and asphalt pavement (Herrador, Perez, Garach \& Ordonez, 2012; Kou, Zhan \& Poon, 2012; Silva, de Brito \& Saikia, 2013). However, in order to sustain these recycling and reusing efforts in terms of commercial and environmental purposes, the potential amount of the concrete waste that can be produced in a batching plant and in

\begin{tabular}{|c|c|c|c|c|c|}
\hline Author(s) & Country & $\begin{array}{l}\text { Number of } \\
\text { construction } \\
\text { materials } \\
\text { observed }\end{array}$ & $\begin{array}{l}\text { Type and number of } \\
\text { projects observed }\end{array}$ & $\begin{array}{l}\text { Observation } \\
\text { period }\end{array}$ & $\begin{array}{l}\text { Average amount of the } \\
\text { concrete waste by weight }\end{array}$ \\
\hline Soibelman (1993) & Brazil & 7 & $\begin{array}{l}4 \text { housing and } 1 \text { commercial } \\
\text { building projects }\end{array}$ & 4-5 months & $13.2 \%$ \\
\hline $\begin{array}{l}\text { Isatto, Formoso, } \\
\text { De Cesare, Hirota \& } \\
\text { Alves (2000) }\end{array}$ & Brazil & 16 & 35 construction projects & 4-6 months & $9.5 \%$ \\
\hline $\begin{array}{c}\text { Bossink and } \\
\text { Brouwers (1996) }\end{array}$ & Holland & 9 & 5 housing projects & 14 months & $3 \%$ \\
\hline $\begin{array}{l}\text { Poon, Yu \& Jaillon } \\
(2004)\end{array}$ & Hong Kong & 10 & $\begin{array}{l}20 \text { public housing projects } \\
\text { and } 2 \text { office blocks }\end{array}$ & $\begin{array}{c}\text { Not } \\
\text { available }\end{array}$ & $3-5 \%$ \\
\hline $\begin{array}{l}\text { Poon, Yu, Wong \& } \\
\text { Cheung (2004) }\end{array}$ & Hong Kong & 11 & 5 housing projects & 20 months & $2.5 \%$ \\
\hline $\begin{array}{l}\text { Tam, Shen \& Tam } \\
(2007)\end{array}$ & Hong Kong & 5 & 18 construction projects & $\begin{array}{c}\text { Not } \\
\text { available }\end{array}$ & $4-6.8 \%$ \\
\hline Baytan (2007) & Turkey & 4 & 8 construction projects & $1-5$ months & $6.1 \%$ \\
\hline Li et al. (2013) & China & 6 & 1 building project & 1 month & $1 \%$ \\
\hline
\end{tabular}


a region should clearly be known. In this respect, a limited number of scientific research studies on the determination of the concrete-focused version of above-mentioned coefficients or percentages exist in the literature to minimize such wastes at inception. Details of these researches are given in Table 1 below.

As can be seen from above-mentioned all percentage values based on scientific researches, the amount of the concrete waste varies in a wide interval changing between $1 \%$ and $13.2 \%$. From the methodological perspective, no research presented in Table 1 has carried out a direct quantitative measurement in places the concrete waste can be born. Numerical values in these studies have been compiled by subtracting the amount of concrete in the bill of quantities from that in project drawings. In other words, these values have been calculated using the following Equation 1 where $V_{\text {percentage }}$ is the percentage of the concrete waste, $\mathrm{V}_{\text {purchased }}$ is the amount or volume of concrete purchased, and $V_{\text {design }}$ is the amount of concrete measured from project drawings,

$\mathrm{V}_{\text {percentage }}=\left(\mathrm{V}_{\text {purchuased }}-\mathrm{V}_{\text {design }}\right) / \mathrm{V}_{\text {design }}$

However, in case of a difference between $\mathrm{V}_{\text {purchased }}$ and $\mathrm{V}_{\text {design }}$, it cannot be asserted that the above-mentioned coefficient for the concrete waste is assigned by the related technical personnel or that the concrete waste is formed. Even a practical difference of $1 \mathrm{~cm}$ between the real position of formwork and its must-be position can lead to a significant deviation especially when the amount of concrete to be poured is very high. In addition, as can be seen from all these previous studies, there is no research investigating the amount of the concrete waste only. This is because in these researches site- or project-focused calculations rather than RMC plant-focused measurements as in the present study have been made due to the high number of different construction materials followed. Therefore, a direct quantitative measurement has been performed neither in RMC plants, where concrete is produced, nor during the discharge of the leftover concrete. In practice, this excessive concrete can be poured in a construction site, in an RMC plant, or during the transportation. In this context, the amount of concrete is not controlled in these three stages, and the concrete waste poured in RMC plants or during the transportation is overlooked. Thus, measurements calculated become prone to serious errors. Moreover, by this methodology, reasons behind the formation of the concrete waste cannot be determined clearly. Therefore, some of above-mentioned studies (Bossink \& Brouwers, 1996; Poon, Yu, Wong \& Cheung, 2004) try to reveal these reasons and their importance levels by means of questionnaire surveys applied to site/project managers instead of employing a direct measurement technique.

Within various categories of the concrete waste, over-order of concrete is the major contributor among others, according to Tam \& Tam (2007). A $f 400$ million of RMC is dumped in the UK each year because construction sites inaccurately order quantities (Fleming, 2000). Similarly, about 8-10 tons of the fresh concrete waste can be produced every day from a batching plant with a daily output of $1000 \mathrm{~m}^{3}$ of concrete (Kou, Zhan \& Poon, 2012). From a global perspective, it is estimated that over 125 million tons of the returned concrete or $0.5 \%$ of the total concrete production are generated as waste every year, confirming that it is a relevant part of the construction waste issue and represents a heavy burden for RMC plants (CSI, 2009). Reasons behind the formation of the fresh concrete waste can be listed as follows, wide-margin orders of contractors' planning engineers for RMC - the amount allowed by quantity surveyors is generally about $10 \%$ more than that in project drawings (Cooke \& Williams, 2004; Tam \& Tam, 2007) because (i) the additional concrete may not be immediately produced especially in busy periods of a batching plant and thus some structurally undesired joints may be formed if the ordered concrete is insufficient and cannot be delivered in time and (ii) estimators find it easier to over specify rather than calculate quantities accurately (Sealey, Phillips \& Hill, 2001), the incorrect calculation of quantity, which is usually based on orders given by workers instead of civil engineers (Kazaz, Ulubeyli \& Turker, 2004), the poor workmanship during the concrete-pouring activity, and the residual or adhesive concrete in truckmixers (Bossink \& Brouwers, 1996; Shen \& Tam, 2002; Poon, Yu, Wong \& Cheung, 2004).

All these reasons and their numerical contributions to fresh RMC waste amounts are also being investigated under the on-going research project. This will clearly reveal the formation process of such wastes.

\section{Measurement of the fresh RMC waste}

This research started in 2013 and will take two years to complete. It is performed with the cooperation of three RMC plants in three cities in Turkey. These cities are Antalya at the south (Mediterranean) coast, Zonguldak at the north (Black Sea) coast, and Isparta situated inland. In choosing them for this research, cities that have different consumption amounts of concrete have been taken into account. Given that the vast majority of structures in Turkey are usually constructed using concrete instead of steel or timber, it can be accepted that the amount of concrete usage is an indicator of the size of the construction market in a city or region. This size likely affects current practices and experience of construction professionals who estimate the amounts of 
materials. In this context, considering the annual RMC consumption data published by TRMCA (2012) and explained in a detailed manner below, the corresponding amount is relatively high in Antalya, average in Isparta, and small in Zonguldak. Thus, in order to represent the general position of the Turkish construction industry to some extent, cities that have construction markets in different sizes were selected.

These three cities have also totally different characteristics in terms of topography and climate which can influence the RMC pouring process. From the topographical perspective, it is possible to have different amounts of RMC waste in truck mixer and in concrete pump during the RMC placing operation in even and uneven grounds. In this regard, Antalya has an even topography, Isparta has a moderately even topography, and Zonguldak has an uneven topography. From the climatic perspective, different temperature and humidity conditions can likely have an impact on the evaporation phase of water in RMC in the transportation and placing stages. In this respect, Antalya is extremely hot and humid, Zonguldak is moderately hot and humid, and Isparta is cool and dry. Overall, it can be accepted that these three cities can likely reflect the average conditions of topography and climate in Turkey.

In order to analyze measurements statistically and remove probable deviations in data to a degree, the number of RMC plants was determined as three. This means that the effect of data-based probable deviations that may occur specific to a plant or a construction market in a city can be decreased. In choosing RMC plants in three cities, plants' production amounts were taken into account. In this context, minimum daily amount to be measured in a plant for single or multiple orders was determined as 100 $\mathrm{m}^{3}$. However, this daily measurement is made in one day per week throughout a year due to resource limitations in the research project. According to TRMCA (2012), daily average RMC production per plant in Turkey in 2011 was approximately $262.2 \mathrm{~m}^{3}$ (=90,450,000 $\mathrm{m}^{3}$ total RMC production in Turkey / 945 RMC plants / 365 days). Thus, from each of three plants, samples that correspond to at least $38.13 \%$ of daily production average of an RMC plant in Turkey are followed and measured. Also, for each variable in Equations 2-7 presented below, minimum 52 values per plant or 156 values in total throughout a year are obtained. As a result, both the rate of samples (38.13\%) and the number of values (52) are statistically adequate, according to Curwin \& Slater (1992).

As RMC plants make extra production especially in spring and summer and usually deliver RMC to different construction sites in almost every hour in a day, it is very hard to follow and measure each production and each order in practice. As a result, it was determined that each of three plants makes RMC production more than this amount. On the other hand, in some days, measurements more or less than $100 \mathrm{~m}^{3}$ have been performed owing to different RMC amounts in orders. This is because in this research order-focused measurements are made instead of project-focused follow-ups. For example, measuring only a $100 \mathrm{~m}^{3}$ part of an RMC order of $300 \mathrm{~m}^{3}$ will be a vain attempt because, as explained in detail below, the amount of order given by a customer has to be compared with the amount delivered in order to calculate the unit waste amount per $1 \mathrm{~m}^{3} \mathrm{RMC}$. In this respect, it is a must to follow and measure the whole amount of an order. Therefore, both single orders of a little more than $100 \mathrm{~m}^{3}$ (e.g., an order of $120 \mathrm{~m}^{3}$ ) and such multiple orders (e.g., three orders of $20 \mathrm{~m}^{3}+60 \mathrm{~m}^{3}+30$ $\left.\mathrm{m}^{3}\right)$ are measured. In case of absence of such orders close to $100 \mathrm{~m}^{3}$, orders that have an average of $100 \mathrm{~m}^{3}$ per day (e.g., $160 \mathrm{~m}^{3}$ in a day and $40 \mathrm{~m}^{3}$ in the next day of measurement) are followed. In fact, this last option is very useful because both small- and large-scale orders can also be followed. Thus, (i) whether the unit waste amount changes with the amount of order and (ii) if so, how this can be numerically explained are investigated.

There is no criterion concerning the selection of samples (i.e., projects where truck mixers in plants go) since it would be a serious constraint to try to find the same type of construction projects constantly. This is compatible with the purpose and content of this research which is about construction projects in general terms. In this context, the variety of project types may ensure that unit waste volumes investigated here are connected with all types of construction projects instead of a particular type of such projects. Therefore, in order to generalize data through this argument, order-focused measurements are made instead of project-focused follow-ups. However, it is of course possible to evaluate data separately for different types of projects.

RMC plants are also followed and their production are constantly controlled throughout a year to determine and minimize the possible seasonal effects on the data, especially concerning the residual RMC in truck mixers. The amount of RMC waste that adheres to the surface and spiral of the drum of a truck mixer is used to find both the efficient volume of the truck mixer and the amount of RMC delivered to a customer. In the follow-up and measurement processes, samples that have to be taken from truck mixers legally by contractors and RMC firms for testing the required characteristics of concrete are not taken into account since they are not regarded as fresh wastes.

The volume of RMC filled into a truck-mixer $\left(\mathrm{V}_{\text {total }}\right)$ by a computerized automatic system in an RMC plant is first calculated by dividing the weight of the total fresh RMC $\left(\mathrm{W}_{\text {total }}\right)$ into the weight of the unit volume of the fresh RMC $\left(\Delta_{\text {concrete }}\right)$ as in Equation 2, 
$\mathrm{V}_{\text {total }}=\mathrm{W}_{\text {total }} / \Delta_{\text {concrete }}$

Second, the residual RMC in the truck-mixer, which cannotred and thereby returns to the plant after the delivery, is taken in the plant by adding some water into the truck-mixer and weighed. Its original weight $\left(\mathrm{W}_{\text {waste }}\right)$ and those of its ingredients (i.e., aggregate, cement, and water) are determined by material experiments in laboratories of the related project-partner university and batching plant. It is of course hard to test whole RMC wastes in truck-mixers because of their huge total amounts. Therefore, before the measurement process in the research, samples were taken from each truckmixer for each class of concrete and were analyzed in detail. As a result, average coefficients were determined to directly calculate original weights of ingredients through the total weight of the fresh residual RMC of which additional water was filtered. This application is periodically performed once three months to observe if these coefficients vary. The sum of original weights of ingredients gives the original weight of the residual RMC in the truck-mixer (Wwaste). The volume of this sum (Vwaste) is calculated by the following Equation 3,

$\mathrm{V}_{\text {waste }}=\mathrm{W}_{\text {waste }} / \Delta_{\text {concrete }}$

Thus, the volume of RMC poured in the site or delivered to the client $\left(\mathrm{V}_{\text {poured }}\right)$ can clearly be expressed as in Equation 4,

$\mathrm{V}_{\text {poured }}=\mathrm{V}_{\text {total }}-\mathrm{V}_{\text {waste }}$

In this context, the possible relationship between $V_{\text {waste }}$ and the volume of the drum of the truck-mixer is also investigated statistically by following truck-mixers of 9,11 , and $12 \mathrm{~m}^{3}$, which are commonly used in the RMC industry. Another possible relationships investigated are between $V_{\text {waste }}$ and the class of concrete and between Vwaste and ingredients' (i.e., sand, gravel, cement, and water) proportions.
As most RMC orders in the construction market are higher than $10 \mathrm{~m}^{3}$, it can be accepted that RMC is usually delivered by more than one truck-mixer. Through Equation 5, the percentage or the unit volume of the residual/adhesive $\mathrm{RMC}$ waste in the truck-mixer $\left(\mathrm{V}_{\text {mixer }}\right)$ is found out. This is the plant-based cause of the concrete waste generation problem. In theory, the drum should be watered both after each order and before idle times. However, in practice, it is usually performed once per truckmixer only at the end of the working day because of busy working conditions of truck-mixers and their operators.

$\mathrm{V}_{\text {mixer }}=\left(\sum_{\mathrm{i}=l}^{\mathrm{n}} \mathrm{V}_{\text {waste-i }} / \sum_{\mathrm{i}=l}^{\mathrm{n}} \mathrm{V}_{\text {total-i }}\right) \times 100$

Client- or contractor-based waste generation factors mentioned above as wide-margin orders, the incorrect calculation of quantity, and the poor workmanship, are also examined in terms of their shares in the unit volume of the RMC waste. As can be given in Equation 6, the potential volume of the RMC waste $\left(\mathrm{V}_{\text {client }}\right)$ depends both on the volume of RMC ordered by client $\left(\mathrm{V}_{\text {ordered }}\right)$ and on the total volume of RMC poured by multiple truck-mixers in site. However, $V_{\text {client }}$ is an imaginary waste unless a truck-mixer returns to the batching plant from site together with the unwanted or unused fresh RMC more than the probable residual/adhesive RMC. This becomes clear when a truck-mixer that has already come back to the plant is weighed. This is because RMC plants produce and deliver RMC step by step as much as the drum of a truck-mixer can include. The production and loading procedure of the whole RMC in a drum takes five minutes only. It means that orders are met in a retail system rather than a wholesale system where all the items of a product are manufactured and wait for the delivery. From another perspective, even if a truck-mixer returns with a considerable amount of RMC, it is sent to another project that demands for a same or smaller class of concrete although it is difficult to match highly specific mix types with suitable customers at short notice. However, if there is no such a project, the returned concrete is called as the fresh waste and only a limited number of the dosing centrals has resources to handle this waste in their yard indeed. Such wastes are also recorded in this research.

$$
V_{\text {client }}=V_{\text {ordered }}-\sum_{i=l}^{n} V_{\text {poured }-i}
$$

Thus, the unit waste volume or percentage that can be used by client $\left(V_{\text {estimating }}\right)$ in estimating the real volume of RMC to be placed is determined through Equation 7,

$\mathrm{V}_{\text {estimating }}=\left(\mathrm{V}_{\text {client }} / \mathrm{V}_{\text {ordered }}\right) \times 100$

Here, as the first option, $\mathrm{V}_{\text {client }}$ can be a negative value. This denotes that the concrete quantity has been calculated incorrectly by client and/or that $\mathrm{V}_{\text {mixer }}$ has been ignored by client and the RMC plant. In contrast, $\mathrm{V}_{\text {client }}$ can be a positive value. In this case, either $\mathrm{V}_{\text {estimating }}$ is allocated by client for order or there can be client-based three causes such as wide-margin orders, the incorrect calculation of quantity, and the poor workmanship. In the present research, these are investigated by means of the direct observation and communication in sites and the direct measurement in RMC plants. While calculating $\mathrm{V}_{\text {estimating, }}$, possible relationships between this value and the type of project or the type of formwork are also examined statistically together with causes behind these relationships.

\section{Conclusions}

In this study, a detailed step-by-step procedure to measure planning and truck-mixer based waste amounts per 1 $\mathrm{m}^{3}$ fresh RMC was presented. This was performed in the light of the formation process of the fresh RMC waste in construction projects. 
As practical/industrial and social implications, waste coefficients that can be obtained by following the procedure explained throughout the present paper can be used by construction contractors and project owners in estimating and accounting and by RMC firms in saving natural resources and energy and in preventing the environmental pollution and potential conflicts between parties. As a research implication, the following values can be computed through unit waste amounts in a future study.

Annual fresh RMC waste production amounts of RMC plants in a country: The total RMC production amount in a country in a year can be multiplied by Vmixer. Also, the share of each class of concrete in this waste amount can be multiplied by the corresponding unit RMC cost. Thus, the estimated cost of the total RMC waste can be determined.

Approximate amounts of ingredients (i.e., aggregate, water, and cement) that can be saved by RMC plants in a country in a year: As proportions of ingredients used for different classes of concrete are recorded in this research, these proportions can be multiplied by the computed waste amount of each class of concrete. Also, these approximate amounts can be multiplied by the corresponding unit costs of these ingredients. Thus, the total cost of savings can be revealed.

Considering this research implication, in the current built environment where the urban transformation is a must in recycling old construction materials, outputs of the on-going research project may largely contribute to the development of the construction industry.

\section{Acknowledgements}

The authors gratefully acknowledge the managers and employees of the batching plants for their generous collaboration and contributions. The authors also thank the financial supports provided by Committees on Research Grants of Akdeniz University and Bulent Ecevit University. This study is based on an on-going research project which is financially supported by the Scientific and Technological Research Council of Turkey (TUBITAK) under the grant number MAG-113M428.

\section{References}

Al-Sari, M.I., Al-Khatib, I.A., Avraamides, M., Fatta-Kassinos, D. (2012). A study on the attitudes and behavioural influence of construction waste management in occupied Palestinian territory, Waste Management and Research 30, 122-136.

Banias, G., Achillas, C., Vlachokostas, C., Moussiopoulos, N., Papaioannou, I. (2011). A web-based decision support system for the optimal management of construction and demolition waste, Waste Management 31, 2497-2502.

Baytan, M. (2007). Origins and Magnitude of Waste in the Turkish Construction Industry, MSc. Thesis, Middle East Technical University, Turkey.

Begum, R.A., Siwar, C., Pereira, J.J., Jaafar, A.H. (2006). A benefit-cost analysis on the economic feasibility of construction waste minimisation: the case of Malaysia, Resources, Conservation and Recycling 48, 86-98.

Bergsdal, H., Bohne, R.A., Brattebo, H. (2007). Projection of construction and demolition waste in Norway, Journal of Industrial Ecology 11, 27-39.

Bossink, B.A.G., Brouwers, H.J.H. (1996). Construction waste: quantification and source evaluation, Journal of Construction Engineering and Management 122, 55-60.

Che Hasan, A.B., Yusof, Z.B., Mohd Ridzuan, A.R.B., Atan, I.B., Noordin, B.B., Abdul Ghani, A.H.B. (2013). Estimation model of construction waste materials in Malaysia: Steel, 2013 IEEE Business Engineering and Industrial Applications Colloquium (BEIAC), Langkawi, Malaysia, pp. 709-713.

Cheng, J.C.P., Ma, L.Y.H. (2013). A BIM-based system for demolition and renovation waste estimation and planning, Waste Management 33, 1539-1551.

Cochran, K.M., Townsend, T.G. (2010). Estimating construction and demolition debris generation using a materials flow analysis approach, Waste Management 30, 22472254.

Coelho, A., de Brito, J. (2011a). Distribution of materials in construction and demolition waste in Portugal, Waste Management and Research 29, 843-853. 
Coelho, A., de Brito, J. (2011b). Generation of construction and demolition waste in Portugal, Waste Management and Research 29, 739-750.

Cooke, B., Williams, P. (2004). Construction Planning, Programming and Control, Blackwell, Oxford.

CSI (The Cement Sustainability Initiative) (2009). Recycling Concrete, World Business Council for Sustainable Development, Switzerland.

Curwin, J., Slater, R. (1992). Quantitative Methods for Business Decisions, zrd Edn., Chapman and Hall, London.

Fleming, D. (2000). Concrete waste costs UK firms over $\mathrm{f} 400 \mathrm{~m}$ a year, Const News 20 July, 18.

Formoso, C.T., Soibelman, L., De Cesare, C., Isatto, E.L. (2002). Material waste in building industry: main causes and prevention, Journal of Construction Engineering and Management 128, 316-325.

Garvin, S. (2004). Construction waste: the bigger picture, Presentation at Seminar "Waste Minimization in Construction - 2004: Saving Money by Reducing Waste", Livingston, Scotland.

de Guzman Baez, A., Villoria Saez, P., del Rio Merino, M., Garcia Navarro, J. (2012). Methodology for quantification of waste generated in Spanish railway construction works, Waste Management 32, 920-924.

Hashimoto, S., Tanikawa, H., Moriguchi, Y. (2009). Framework for estimating potential wastes and secondary resources accumulated within an economy - a case study of construction minerals in Japan, Waste Management 29, 2859-2866.

Hendriks, C.F., Pietersen, H.S. (2000). Sustainable Raw Materials: Construction and Demolition Waste, Report 22, RILEM Publications, France.

Herrador, R., Perez, P., Garach, L., Ordonez, J. (2012). Use of recycled construction and demolition waste aggregate for road course surfacing, Journal of Transportation Engineering 138, 182-190.

Hoglmeier, K., Weber-Blaschke, G., Richter, K. (2013). Potentials for cascading of recovered wood from building deconstruction - a case study for south-east Germany, Resources, Conservation and Recycling 78, 81-91.

Hsiao, T.Y., Huang, Y.T., Yu, Y.H., Wernick, I.K. (2002). Modeling materials flow of waste concrete from construction and demolition wastes in Taiwan, Resources Policy 28, 39-47.

Isatto, E.L., Formoso, C.T., De Cesare, C.M., Hirota, E.H., Alves, T.C.L. (2000). Lean Construction: Guidelines and Tools for Controlling Waste in Building, SEBRAE/RS, Porto Alegre, Brazil.

Jaillon, L., Poon, C.S., Chiang, Y.H. (2009). Quantifying the waste reduction potential of using prefabrication in building construction in Hong Kong, Waste Management 29, 309320.

Kartam, N., Al-Mutairi, N., Al-Ghusain, I., Al-Humoud, J. (2004). Environmental management of construction and demolition waste in Kuwait, Waste Management 24, 1049-1059.

Katz, A., Baum, H. (2011). A novel methodology to estimate the evolution of construction waste in construction sites, Waste Management 31, 353-358.

Kazaz, A., Ulubeyli, S., Turker, F. (2004). The quality perspective of the ready-mixed concrete industry in Turkey, Building and Environment 39, 1349-1357.

Kelly, M., Hanahoe, J. (2008). The development of construction waste production indicators for the Irish construction industry, in: $M$. Zamorano, C.A. Brebbia, A. Kungolos, V. Popov, H. Itoh (Eds.), Waste Management and the Environment Iv, pp. 499-508.

Kerzner, H. (2009). Project Management: a Systems Approach to Planning, Scheduling and Controlling, 1oth Edn., John Wiley and Sons, New Jersey.

Kibert, C.J. (2000). Deconstruction as an essential component of sustainable construction, Second Southern African Conference on Sustainable Development in the Built Environment, Pretoria, 1-5.

Kofoworola, O.F., Gheewala, S.H. (2009). Estimation of construction waste generation and management in Thailand, Waste Management 29, 731-738.

Kou, S., Zhan, B., Poon, C. (2012). Feasibility study of using recycled fresh concrete waste as course aggregates in concrete, Construction and Building Materials 28, 549-556.

Kourmpanis, B., Papadopoulos, A., Moustakas, K., Kourmoussis, F., Stylianou, M., Loizidou, M. (2008). An integrated approach for the management of demolition waste in Cyprus, Waste Management and Research 26, 573-581.
Lage, I.M., Abella, F.M., Herrero, C.V., Ordonez, J.L.P. (2010). Estimation of the annual production and composition of C\&D Debris in Galicia (Spain), Waste Management 30 , 636-645.

Lau, H.H., Whyte, A., Law, P.L. (2008). Composition and characteristics of construction waste generated by residential housing project, International Journal of Environmental Research 2, 261-268.

Lewis, J.P. (2001). Project Planning, Scheduling, and Control: a Hands-On Guide to Bringing Projects in on Time and on Budget, 3rd Edn., McGraw-Hill, New York.

Li, J.R., Ding, Z.K., Mi, X.M., Wang, J.Y. (2013). A model for estimating construction waste generation index for building project in China, Resources, Conservation and Recycling 74, 20-26.

Li, Y., Zhang, X. (2013). Web-based construction waste estimation system for building construction projects, Automation in Construction 35, 142-156.

Llatas, C. (2011). A model for quantifying construction waste in projects according to the European waste list, Waste Management 31, 1261-1276.

Malia, M., de Brito, J., Pinheiro, M.D., Bravo, M. (2013). Construction and demolition waste indicators, Waste Management and Research 31, 241-255.

Masudi, A.F., Hassan, C.R.C., Mahmood, N.Z., Mokhtar, S.N., Sulaiman, N.M. (2011). Quantification methods for construction waste generation at construction sites: a review, Advances in Material Research 163167, 4564-4569.

McDonald, B., Smithers, M. (1998). Implementing a waste management plan during the construction phase of a project: a case study, Construction Management and Economics 16, 71-78.

de Melo, A.B., Goncalves, A.F., Martins, I.M. (2011). Construction and demolition waste generation and management in Lisbon (Portugal), Resouces, Conservation and Recycling 55, 1252-1264.

Mercader-Moyano, P., Ramírez-de-ArellanoAgudo, A. (2013). Selective classification and quantification model of $C \& D$ waste from material resources consumed in residential building construction, Waste Management and Research 31, 458-474. 
Mokhtar, S.N., Mahmood, N.Z., Hassan, C.R.C., Masudi, A.F., Sulaiman, N.M. (2011). Factors that contribute to the generation of construction waste at sites, Advances in Material Research 163-167, 4501-4507.

Mulheron, M. (1988). The recycling of demolition debris, current practice, products and standards in the United Kingdom, Proceedings of the Second International RILEM Symposium, Tokyo, Japan, 510-519.

Nagapan, S., Rahman, I.A., Asmi, A., Adnan, N.F. (2013). Study of site's construction waste in Batu Pahat, Johor, Procedia Engineering 53, 99-103.

Poon, C.S. (2007). Reducing construction waste, Waste Management 27, 1715-1716.

Poon, C.S., Yu, A.T.W., Jaillon, L. (2004). Reducing building waste at construction sites in Hong Kong, Construction Management and Economics 22, 461-470.

Poon, C.S., Yu, A.T.W., Wong, S.W., Cheung, E. (2004). Management of construction waste in public housing projects in Hong Kong, Construction Management and Economics 22, 675-689.

Ritz, G.J. (1994). Total Construction Project Management, McGraw-Hill, New York.

Saez, P.V., Merino, M.D., Porras-Amores, C. (2012). Estimation of construction and demolition waste volume generation in new residential buildings in Spain, Waste Management and Research 30, 137-146.

Sealey, B.J., Phillips, P.S., Hill, G.J. (2001). Waste management issues for the UK ready-mixed concrete industry, Resources, Conservation and Recycling 32, 321-331.

Shen, L.Y., Tam, W.Y.V. (2002). Implementing of environmental management in the Hong Kong construction industry, International Jounal of Project Management 20, 535-543.

Silva, R.V., de Brito, J., Saikia, N. (2013). Influence of curing conditions on the durability-related performance of concrete made with selected plastic waste aggregates, Cement and Concrete Composites 35, 23-31.

Soibelman, L. (1993). Material Waste in Building Construction: Occurrence and Control, MSc. Dissertation, Federal University of Rio Grande do Sul, Porto Alegre, Brazil.

Solis-Guzman, J., Marrero, M., Montes-Delgado, M.V., Ramirez-De-Arellano, A. (2009). A Spanish model for quantification and management of construction waste, Waste
Management 29, 2542-2548.

Stokoe, M.J., Kwong, P.Y., Lau, M.M. (1999). Waste reduction: a tool for sustainable waste management for Hong Kong, R'99 World Congress, Geneva, 165-170.

Tam, V.W.Y. (2008). On the effectiveness in implementing a waste-managementplan method in construction, Waste Management 28, 1072-1080.

Tam, V.W.Y., Tam, C.M. (2007). Economic comparison of recycling over-ordered fresh concrete: a case study approach, Resources, Conservation and Recycling 52, 208-218.

Tam, V.W.Y., Shen, L.Y., Tam, C.M. (2007). Assessing the levels of material wastage affected by sub-contracting relationships and projects types with their correlations, Building and Environment 42, 1471-1477.

Tamraz, S.N., Srour, I.M., Chehab, G.R. (2011). Construction demolition waste management in Lebanon, International Conference on Sustainable Design and Construction (ICSDC) 2011: Integrating Sustainability Practices in the Construction Industry, Kansas City, USA, pp. 375-383.

TRMCA (Turkish Ready-Mixed Concrete Association) (2012). Statistics of the ReadyMixed Concrete Industry in 2011, TRMCA, Istanbul.

TRMCA (Turkish Ready-Mixed Concrete Association) (2014). Statistics of the ReadyMixed Concrete Industry in 2013-2014, TRMCA, Istanbul.

Wimalasena, B.A.D.S., Ruwanpura, J.Y., Hettiaratchi, J.P.A. (2010). Modeling construction waste generation towards sustainability, Construction Research Congress 2010: Innovation for Reshaping Construction Practice, Banff, Canada, pp. 1498-1507.

Winkler, G. (2010). Recycling Construction and Demolition Waste, McGraw-Hill, New York. 